\title{
THE HYDROFLUVIAL IMPORTANCE OF LP GAS TRANSPORTATION IN THE AMAZON AND ITS IMPLICATIONS
}

\author{
LUIZ EDUARDO BENTES DIAS \& JUSSARA SOCORRO CURY MACIEL \\ Federal Institute for Technological Education of Amazonas, Brazil
}

\begin{abstract}
This paper purposes to offer a systematic analysis of the Liquefied Petroleum Gas hydro fluvial transport infrastructure in the state of Amazonas, Brazil and its implications in the municipality supplies and to Amazon development. It aims to highlight the improving infrastructure importance for the expansion of this product to the State economy, besides the logistical problems of this type of transportation. Each year the drought leads to reduced water levels, and interrupted the regular shuttle ferries in some state rivers. Data was collected from a Liquefied Petroleum Gas company that serves the entire state of Amazonas and, with the information collected, it was possible to observe the municipalities consume and understand the possible causes. This study proposes some alternative solutions, which may contribute to broader debates and also signal to urge the evaluation of logistics alternatives that meet the business particularities, respecting the environment and communities in the region. However, this methodology analyzed the cities served by the gas supply in 2016, selecting those with higher and lower consumption to check the real reasons involved beyond the population amount. It was also analyzed the reason each city consumes such demand of this product and each case relation with the transport infrastructure so that the product could reach the final consumer. Analyzing the LP Gas consumption data of the five largest and smaller municipalities, it is clear that cities that are in the pipeline of the Solimões-Amazonas Waterway are those that have a higher and efficient supply of LP Gas. Nevertheless, it was presented at a certain time of the year that this transport type becomes unfeasible due to change in river levels. Therefore, an improved system of cabotage is necessary where the vessels came to a certain municipality and could have a strategic base for the redistribution through hydrofluvial transportation or even rural roads.
\end{abstract}

Keywords: fluvial transport, amazonas, GLP.

\section{INTRODUCTION}

Brazil's waterway transport is a segment of multimodal infrastructure that integrates the country through its water resources. It is divided into maritime and fluvial modalities, in which its cargo transport capacity per kilometer is greater than that of the road modal, which ends up making this modal a cheaper option, taking into account the economic aspect. There are regions, however, that depend almost exclusively on this modality, as is the Amazon situation, where the distances are great and the roads or railways do not exist [1].

The importance of an adequate economic infrastructure for a development environment generation has been recognized. Several authors have discussed infrastructure importance in productive inputs provision - such as water, energy, transportation, and others - to the economic growth and poverty reduction and social inequality [2]. Despite the greater recognition given to adequate infrastructure improvements, many developing countries still invest little in this area.

However, in the search for competitiveness, when related to reliability, shorter transport time, quality and mainly routes, the companies have been giving more emphasis on two different modes of cargo transfer, the intermodal or the multimodal. Studies show that the multimodal transport brings benefits to the logistical chain. The companies become more 
competitive and integrated within the markets, besides increasing the regional development and the social integration in the frontier countries [3]-[6].

In the State of Amazonas, as well as in the Amazon region itself, river transport is vital for the survival of the Amazon basin supply, the economic and social region development, and the environmental and social aspects of the population. This process requires a good performance of the river transport services [7].

The navigation segment has good expectations regarding the navigation in the rivers, mainly in the Madeira River, in the flood period. In view of the waterway transport importance and challenges, the study objective was to analyze the success of the Liquefied Petroleum Gas fluvial transportation and the main challenges faced by the private sector to make a correct product distribution, from its acquisition to the final consumer, highlighting the specialists in hydrofluvial transport point of view.

\section{METHODOLOGY}

The methodological approach adopted in this study is based on bibliographical research where the subjects are presented in a systematic way, besides the exploratory research based on papers published and based on information obtained through partial data queries in a company that transports and distributes LP Gas in Amazonas State. However, such methodology revealed the reliable and solid results in this study discourse.

In this study context, the region's economy is analyzed, specifically in the five largest cities where demand for LP Gas is very high, as well as in the other five smaller cities, where demand for LPG is very small, it took into account the data obtained in April 2016. These data are extremely important in the work result, because through them, it was possible to detect the main deficiencies and difficulties found in this transport process, in order to point out improvements always taking into account the cost-benefit relation and the type of transport used for a particular purpose. It was also analyzed the reason for each city consuming such demand of this product and relating each case with the transportation infrastructure so that this product reaches the final consumer.

Through the research in the LP Gas Distributor and data collection, we have Table 1 that classifies five largest and smallest city consumers of LPG in Amazonas, in order to verify the distance, type and time in transportation interference, besides searching the factors that may be related to the presented reality.

Table 1: Major and minor cities consumers of LP Gas supplied by waterways, in April 2016. (Source: Personal Research at Society Fogás LTDA.)

\begin{tabular}{|c|c|c|c|c|}
\hline City & Amazonas Region & Population & River & $\begin{array}{c}\text { Monthly } \\
\text { Consumption }(\mathrm{Kg})\end{array}$ \\
\hline Tabatinga & Southwest & 62.346 & Solimões & $569,405.00$ \\
\hline Coari & Center & 83.929 & Solimões & $370,814.00$ \\
\hline Tefé & Center & 62.230 & Solimões & $366,840.00$ \\
\hline Parintins & Center & 112.716 & Amazonas & $361,433.00$ \\
\hline Borba & South & 39.885 & Madeira & $278,139.00$ \\
\hline Anori & Center & 18.826 & Solimões & $17,930.00$ \\
\hline $\begin{array}{c}\text { Santa Isabel do Rio } \\
\text { Negro }\end{array}$ & North & 22.404 & Negro & $15,350.00$ \\
\hline Japurá & North & 5.125 & Japurá & $12,318.00$ \\
\hline Canutama & South & 14.944 & Purus & $9,347.00$ \\
\hline Autazes & Center & 37.752 & Madeira & $9,347.00$ \\
\hline
\end{tabular}




\section{HYDROFLUVIAL TRANSPORT SYSTEM}

In a continental country such as Brazil, it would be relevant to have the exploring feasibility in different transportation modes. The same observation applies to the extensive and little explored Brazilian watershed, mainly the Amazon, more precisely in Amazonas [8]. The transport modes integration is also a much-discussed subject and a point to be improved in this country.

The geographical and climatic characteristics of Amazonas contribute to adversity in accessibility, in addition, the fact that most of the ports are inadequate for the transportation of cargoes and people. All of these factors contribute to limiting the Amazonian products competitiveness limit, mainly in the Manaus Industrial Complex, called PIM, which is still dependent on raw materials and imported inputs [8].

For Handabaka (2006), the Amazon basins, Silver and Orinoco, with more than 10 thousand square, constitute an important axis to Latin America; the North-South fluvial axis is the largest navigation corridor in the world. To the north of the South American continent near the equator line, lies the Amazon basin with an extension of approximately $6,600 \mathrm{~km}_{2}$. One of the most economically important cities in the area is Manaus. With its logistics platform, it connects Brazil and other continents, becoming the main cargo transfer area, and consequently discharging the industrial production to Manaus Industrial Pole [9].

The small share of the waterways in the country's transportation matrix is associated with the geographical concentration of water transport in the North, which accounts for $90 \%$ of cargo handling by waterways, but accounts for only $4.6 \%$ of the national GDP. There are four basic physical elements that make up a waterway project: roads, boats, cargoes and terminals. For each of them, environmental and socioeconomic aspects should be considered in the planning, implementation and operation phases of transport infrastructure [10]. Most small towns in the interior of the Amazon do not have port facilities; loading and unloading operations are carried out on small piers or on the bank slopes, absolutely without structure.

The Amazon Basin meets the ideal conditions for this transportation type. With a water volume of $1 / 5$ of the fresh water world's availability, the Amazon has 25,000 km of waterways, being navigable about $16,000 \mathrm{~km}$, which corresponds to $60 \%$ of the national waterway network, such as the Black, The Solimões, Amazonas, Branco, Juruá, Madeira and Purus. The main public ports are: Manaus, Belém, Porto Velho, Macapá and Santarém. [11].

The city of Manaus is the largest generator of cargo transportation in the Amazon region [11]. Due to the peculiarities of the region, the transportation is carried out in the fluvial mode, using the roll on / roll off system in the intermodal terminals. This modality accounts for $82 \%$ of all general cargo transportation from the region to the rest of the country.

"The hydrographic system, as we see in (Fig. 1) is represented by the central rail - a real East-West Avenue of access to the Atlantic and to the heart of the continent - opened the oceanic navigation from Belém and Macapá, in mouth, to Iquitos in Peru, a journey of more than $3,500 \mathrm{~km}$, and the extensive network of tributaries which penetrate to the South and the North of the basin According to an orthogonal pattern, or in form of fish-spine." [12].

The Administration Studies of the Western Amazon Waterways reveal that the main critical points that hinder navigability in the cargo and passenger's transportation in the Solimões River are: (i) river banks erosion; (ii) sedimentation in the river bed; (iii) sand banks formation; (iv) narrowing of the canal; (v) decreasing the channel depth due to sedimentation; (Vi) closing the canal in some river stretches; (vii) non-flagged pedals; (viii) presence of tree trunks within the canal [13]. 


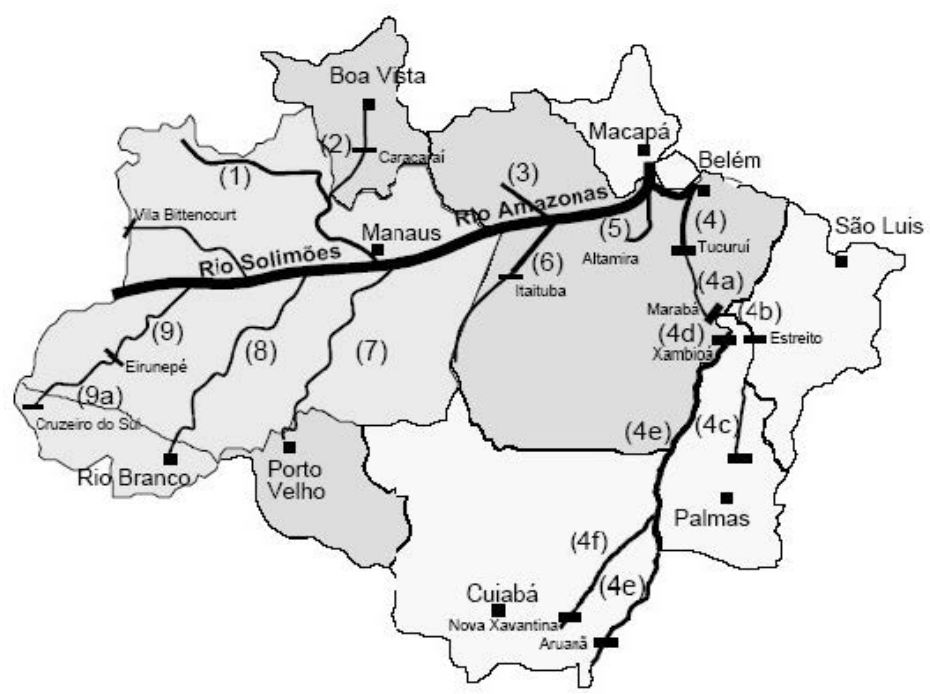

Figure 1: Waterway network of the Amazon [15].

It is worth mentioning the Manaus Industrial Pole, called PIM, which is the most important productive agglomeration of the region, which boosted Manaus growth from the end of the 60's. Among its characteristics, the following stand out: a) Greater electroelectronic pole of Latin America; b) $1.5 \%$ of Brazil PIB; c) $10 \%$ of Brazilian companies with ISO have benefits of Import Taxes and ICMS, more than 450 Industries and US \$4 billion of accumulated fixed assets [14].

\section{LP GAS TRANSPORTATION AND DISTRIBUTION IN AMAZONAS}

We acquire LPG as a naturally occurring product of the natural gas extraction process or as an automatic result of the oil refining production process [16]. As a low carbon, low polluting fossil fuel, it is recognized by governments all around the world for the contribution, it can make towards improved indoor and outdoor air quality and reduced greenhouse gas emissions.

LPG is petroleum derived colourless gas, consists of propane or butane or from mixtures of both. In everyday usage, different mixtures are used depending on the climatic nature of every region. Butane has higher caloric value, but in colder countries more propane must be used in mixture, because propane evaporates at lower temperatures. LPG has a high-octane rating of 112 which enables higher compression ratios to be employed and hence gives higher thermal efficiency. All better conversation systems which are present in the market have low maintenance costs [17]. This product is widely used in the country, both in residences as in commerce and industry. There are plenty of applications: food cooking, water heating and industrial furnaces, among many others that help to move Brazil's economy [18].

The Solimões Basin is one of the largest onshore oil exploration in the country [19]. Accompanied by strict quality control, oil and LPG follow along 285 kilometers of pipeline extension, connecting the Urucu production area to the Solimões Terminal, located 16 kilometers from Coari Municipality. At this terminal, in Solimões River banks, oil and LPG 
are shipped in oil tankers and butane or propane (gas) ships, to the Isaac Sabbá Refinery in Manaus, and to other parts of the Country North and Northeast.

Once the LPG disembarks at the Refinery, the distributor buys the same, and receives it through pipelines, and thus begins its entire process of packaging and distribution.

The LPG distribution system in the State of Amazonas uses water transport, in great part, and road transport in some specific countryside. In some cases, these two transport types are used for the same load thus making the transport system in a multimodal transport. This system is composed by an extensive river network, which is the true vocation of regional transport, due to the State vast hydrographic wealth, with some terminals implanted, and a restricted road network still adjacent to Solimões River basin influenced area that serves only as a complement to the waterway transport system. After bottling it is shipped in private ports, always allocated in rafts with pushers (Fig. 2), where each ferry has its own route already defined, always according to the LPG shipped capacity and the number supplied cities.

The route is made via the Solimões-Amazonas waterway, which is composed of a main axis, formed by the bed of the Solimões River, and its main tributaries: Purus, Javari, Juruá, Urucu, Içá and Japurá.

This type of navigation should preferably be carried out in the period of high waters, which runs from February to June, with an eight-meter draft, decreasing in the dry season, from July to November, to about 4 meters. Due to the dry season, it runs from September to November, there may be restrictions on navigation in some parts of the Solimões River. In this case, transshipment is carried out with a ferry to the height Codajás Island with anchor ship. This trip takes about 20 days and takes an expressive LPG amount in bottles of 5, 8 and $13 \mathrm{Kg}$.

Another destination to be highlighted is the LPG transportation in bulk (Fig. 3), which supplies the city of Porto Velho in Rondônia, and the city of Santarém in Pará, both Brazilian States, where the vessel leaves from the city of Manaus towards the Petroleum Derivatives Terminal, located in the city of Coari, and from there it is loaded in tanks with high LPG storage capacity.

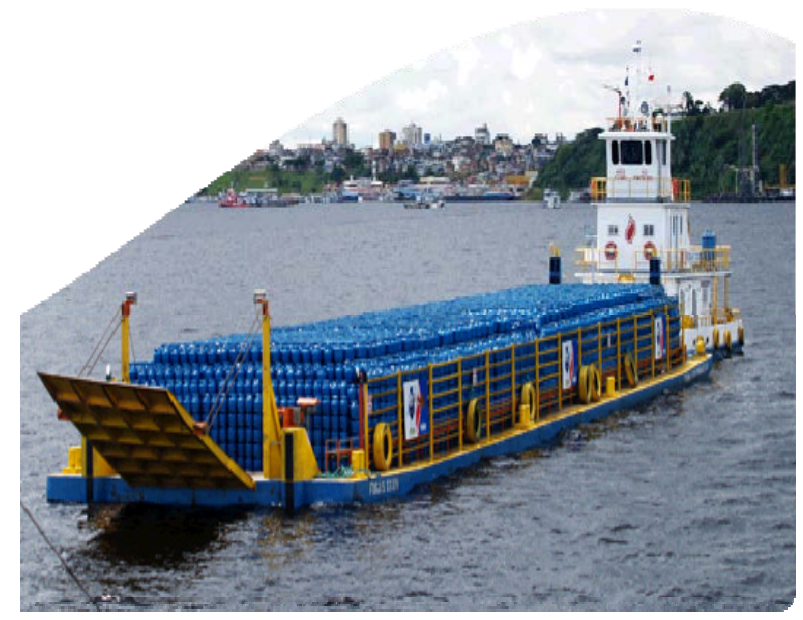

Figure 2: Ferry boat with LPG on the way to Municipalities in the State of Amazonas [20]. 


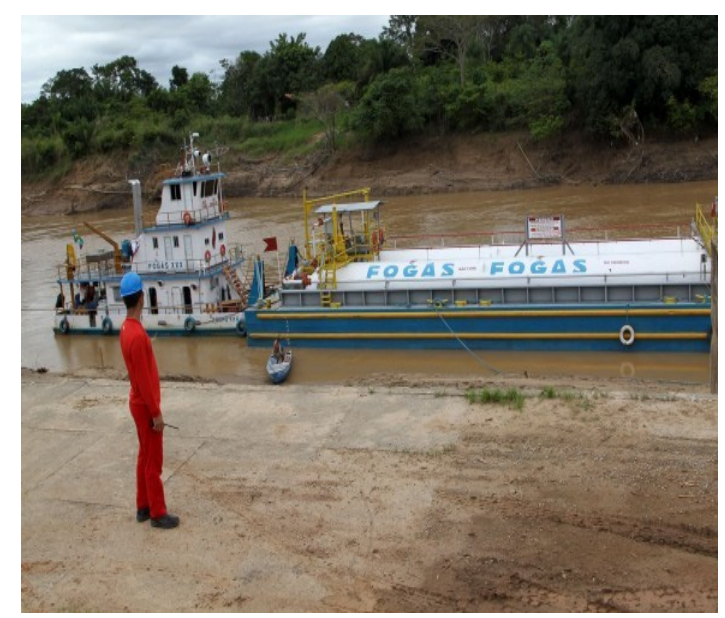

Figure 3: Ferry boat with GLP to Porto Velho in Rondonia [21].

\section{LP GAS CONSUMPTION DETAILED ANALYSIS FROM AMAZONAS CITIES}

1. Coari: It is a city in the interior of Amazonas State. In this area, Petrobras Urucu platform is located, where oil and gas are extracted. Near the city, is installed the TRANSPETRO Waterway Terminal (Petrobras subsidiary), which receives gas and oil through two pipelines, gas and oil, which are transported by ships to Manaus and other regions of the Northeast. According to the data collected, this city is one of the largest consumers of LP Gas, because it is one of the most populous cities in Amazonas State, in addition, this countryside is one of the most developed rural areas, and this has a direct influence on LP Gas consumption. Another factor that influences this value of LP Gas commerce is the fact that Coari is located on the Solimões River, which is the main waterway in the state of Amazonas, and has a constant flow of boats leaving towards that city

2. Tabatinga: City located in the western state of Amazonas, on the triple border between Brazil, Colombia and Peru. Because it is one of the most populous cities in Amazonas, it consumes a high value of LPG, with the Solimões-Amazonas waterway as the main route for the input distribution.

3. Tefé: The high consumption of LPG is directly related to the distance to the state capital, in addition it is one of the most populous cities and has a very active economy.

4. Parintins: It is the second most populous city of the State of Amazonas, consequently this entails a high consumption of LPG, becoming the second one. Another factor that influences this consumption is the proximity of the metropolitan region and the LPG quantity of cargoes shipped monthly by the Amazon River to this state region.

5. Borba: It is a bathed city located on Madeira River banks, being one of the main LPG consuming cities. This is due to the fact that there is cargo landing, including LPG, weekly.

6. Anori: The low consumption of this Municipality is justified by the terrestrial transport used, and a small part by fluvial water transport. In this context, this city 
ends up being hampered by the difficulty of a more efficient transportation system, or alternative road or improvement of waterways as well.

7. Santa Isabel do Rio Negro: The distance is the crucial factor of the city low consumption, which influences the transport of LPG to the Municipality, besides, the demand is small, due to the low demographic occupation.

8. Japurá: As well Santa Isabel do Rio Negro, the city of Japurá is very far from the state capital, and this causes a minimum consumption of LPG, in addition to that this Municipality has one of the smallest population contingent.

9. Canutama: This city population is very small comparing with the others, and also because in this municipality has more than one gas supplier and this generates a lower LPG demand.

10. Autazes: It is characterized as a small consumer of LPG, due to the use of terrestrial transport to the gas supply, however some specific customers as floating dealers, the so-called "pontoons", are supplied through waterway transport.

\section{CONCLUSIONS}

As discussed in this research, in relation to LP Gas transportation, Solimões-Amazonas waterway is the best alternative to be used in the state and to others, cause the cabotage and the long river course. This importance to the LP Gas transport is evident, mainly due to the lack of roads and rail network in the region, which makes the rivers essential for the supply of regional cities such as Manaus. Besides, there are the significant imported container volumes and the imported fuel arriving by this route.

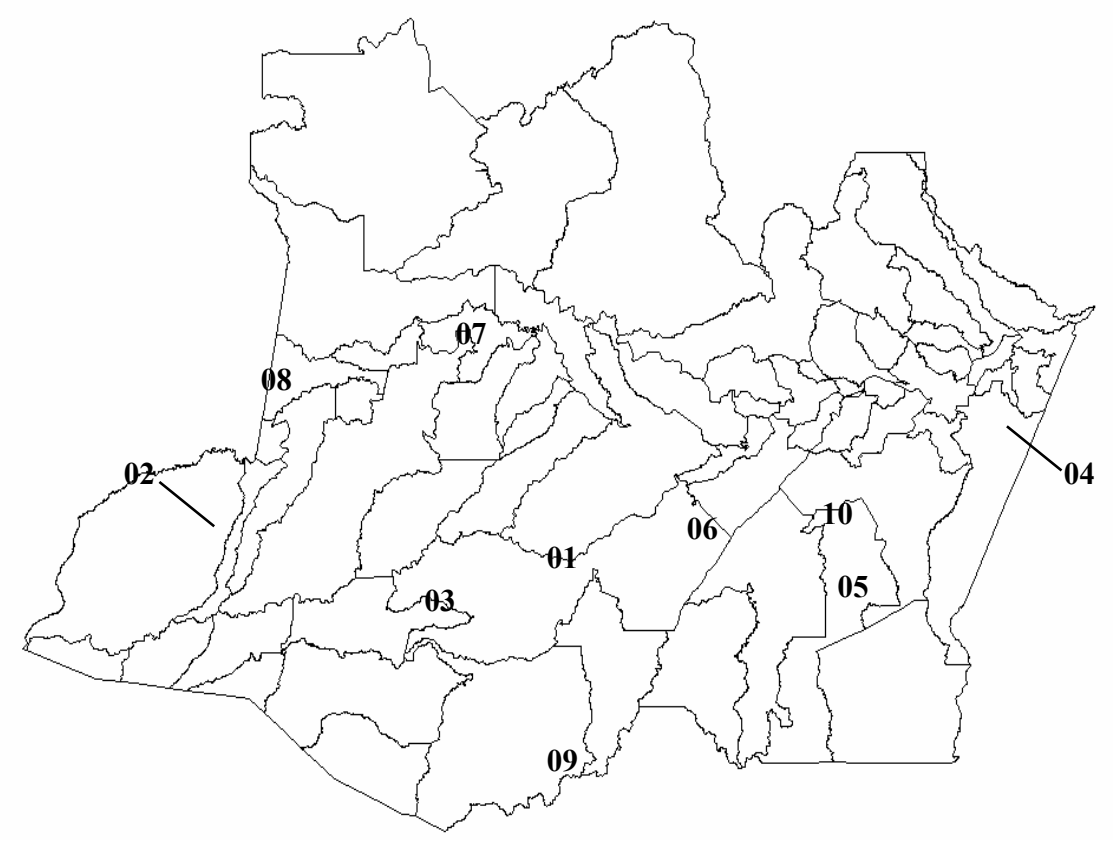

Figure 4: Geographic location of the cities analyzed in this paper [22]. 
Therefore, from the national logistics perspective, Amazonas-Solimões waterway has a strategic position, these waters transversely cut across the north of the country, connecting with the Midwest through the Madeira River and its mouth, along the Atlantic Ocean almost on the equator, provides greater proximity to loads with European and North American markets, in comparison to the southern and southeast ports. The external aspects should be taken into account to the construction implementation needs and the waterway maintenance projects.

Thus, there are many challenges to developing large-scale river transport in Amazon. It is necessary to reverse decades of the prioritization absence, imposed by the various governmental investment models of the region. Among the existing modalities, fluvial is the cheapest, and it can fully meet the needs of freight and people transportation, if there are economic and structural investments appropriate to their trafficability.

Finally, when analyzing the LPG consumption data of the five largest and five smaller Municipalities, it can be seen that the cities that are in the Solimões-Amazonas waterway are those with a higher and more efficient LPG supply. However, at certain times of the year this type of transport becomes impracticable due to the river levels changes.

Therefore, it is necessary to have an improved cabotage system where the vessels reach a certain municipality could have a strategic basis for redistribution, by means of hydro fluvial transport or even by road transport, using the rural roads.

It is recommended that this paper study could be continuously researched, both theoretically and practically, in order to find alternatives for improving the transportation infrastructure quality of LP Gas in and other cargoes in Amazonas.

\section{REFERENCES}

[1] Agência Nacional De Transportes Aquaviários. Plano Nacional de Logística e Transportes. Available at http://www.antaq.gov.br. Accessed in May 2016.

[2] Briceño-Garmendia, C., Estache, A. \& Shafik, N. (2004). Infrastructure Services in Developing Countries: Access, Quality, Costs and Policy Reform. In: A infraestrutura Econômica do Brasil- Diagnósticos e Perspectivas para 2025, IPEA 2010.

[3] IIRSA. Iniciativa para la integración de la Infraestructura Regional Suramericana. IIRSA. Banco Iteramericano de Desarrolho, 2006.

[4] Novaes, A.G., Logística da cadeia de distribuição. 2nd ed. Elsevier: Rio de Janeiro, 2004.

[5] Tsamboulas, D.A., A tool for prioritizing multinational transport infrastructure investments. Transport Policy, 15, p. pp. 11-26, 2007.

[6] Zhang, A., Lang, C., Hui, Y.V. \& Leung, L., Intermodal alliance and rivalry of transport chains: The air cargo market.

[7] Duarte, R.C.D.S., Kuwahara, N.E. \& Alencar, L.A., (2009), Perspectiva ergonômica para embarcações do estado do Amazonas. In XXIII ANPET - Congresso de pesquisa e Ensino em Transportes, Vitória.

[8] Kuwahara, N., Neto, J.C.L. \& Abensur, T.C., Modelagem de previsão de navegabilidade em rios da Amazônia: ferramenta web de suporte aos usuários do transporte aquaviário. In Journal of Transport Literature, 6(3), pp. 60-89, 2012.

[9] Handabaka, A.R., Corredores interoceánicos sudamericanos: critérios logísticos de selección. Lima: Fimart S.A.C. Editores e Impresore, 2006.

[10] Santana, W. A. \& Tachibana, T., Caracterização dos Elementos de um Projeto Hidroviário, Vantagens, Aspectos e Impactos Ambientais para a Proposição de Metodologias Técnico-ambientais para o Desenvolvimento do Transporte Comercial 
de Cargas nas Hidrovias Brasileiras. In ENGEVISTA, 6(3), p.75-85, Rio de Janeiro, 2004.

[11] Bnds, Banco Nacional do desenvolvimento. Transporte na Região Amazônica. Cadernos de Infraestrutura n. 7, BNDES 114 p., Rio de Janeiro, 1998. Available at http://www.bndespar.gov.br. Accessed on: Oct. 2016.

[12] Carvalho, L.C.C., Logística de Abastecimento de Derivados de Petróleo na Região de Influência da Refinaria instalada em Manaus: Estudo de Viabilidade. Dissertação de Mestrado em Engenharia de Produção, Universidade Federal de Santa Catarina, Florianópolis, 2002.

[13] Petcon, Estudo de Transporte e Fluxo de Cargas do Rio Solimões. In: AHIMOC Administração das Hidrovias da Amazônia Ocidental. Relatório Final Planejamento em Transporte e Consultoria Ltda. Brasília, 2002.

[14] Suframa, Superintendência Da Zona Franca De Manaus. Relatório de Indicadores de Desempenho do Polo Industrial de Manaus, http://www.suframa.gov.br/. Accessed on: Mar. 2016.

[15] BNDS-Cadernos de Infra-Estrutura do BNDES- http://www.bndes.gov.br/ conhecimento/cadernos. Accessed on: Aug. 2016.

[16] SHV GAS. Why LPG? - Brochure, from http://whylpg.shvgas.com. Accessed on Oct. 2016.

[17] LP-GAS CODE, Handbook. Fifth Edition.ed. Theodore C. Lemoff. P.E, With the complete texto f the 1998 edition of NFPA 58, Liquefield Petroleum Gas Code. Quincy, Massachusetts, 1998.

[18] SINDIGÁS. Transporte na Região Amazônica.O Gás LP do Brasil, 7 p., Rio de Janeiro, 2013. Available at www.sindigas.org.br. Accessed on: Oct. 2016.

[19] MME. Ministério das Minas e Energia. Boletim de exploração e produção de petróleo e gás natural, 3 p., Rio de Janeiro, 2016. Available at www.mme.gov.br. Accessed on: Sep. 2016.

[20] Research Part E, pp. 234-246, 2007.

[21] Fogás. A sua história e atuação. Available at https://www.fogas.com.br/afogas. Accessed on: Oct. 2016.

[22] Marcel, Y. Balsa com 450 toneladas de gás de cozinha chega à Rio Branco. G1/Acre, Rio Branco, 16 Abril. 2014. Disponível

[23] em:< http://g1.globo.com/ac/acre/noticia/2014/04/balsa-com-450-toneladas-de-gasde-cozinha-chega-rio-branco.html>. Accessed on: Oct. 2016.

[24] Map created by the author with the help of the ArcGIS Platform. 